\title{
Shadows of Orientalism in Portugal - Some Notes on Theories and Practices in Macao early narrative images (16th and 17th centuries)
}

\author{
Ana Paula AVELAR \\ CHAM, FCSH, Universidade NOVA de Lisboa, Univerisdade dos Açores, \\ Lisboa, Universidade Aberta, Lisboa, Portugal \\ ana.avelar@uab.pt
}

\begin{abstract}
Imperial Portuguese imagery unveils three discursive tropes as primordial signs of the representation of an idea of empire - the cross, the crown and the sphere. These three signs embody the representation of the Portuguese monarchy since the remote 16 th century and play a role in the building of an Orientalism in Portugal. Having in mind the notion of Orientalism as an ongoing conceptual building, I will approach the first narrative images of Macao that emerge in reports about the Portuguese presence in that space.

My focus will lie on Duarte Barbosa's and Tomés Pires' texts, and on Fernão Lopes de Castanheda's and Gaspar da Cruz's chronicles, in order to show how space summons the imagery of a historical time. In these texts, we are not yet before an idea of progress, since they only confront the different, either incorporating or rejecting it.
\end{abstract}

Keywords: Empire; Macao; representation; chronicles; imagery

It is impossible to ponder on the topic Shadows of Orientalism in Portugal Macao early narrative images (16th and 17 th centuries) without having in mind that Portuguese imperial imagery unveils primordial signs such as the crown, the cross, and the sphere.

These signs represent, at a symbolical level, the Portuguese monarchy since King Manuel's reign, from the late fifteenth-century to early sixteenth (1495-1521) and play a relevant role in the building of an orientalism in Portugal.

This orientalism must be conceived as those narrative practices where the "art" of description, communication, and representation unfold. These discursive practices reveal economic, social and political purposes while emerging under different aesthetic forms (Avelar, 2010: 83).

They encapsulate an orientalism that derives itself from the way colonialism has evolved. It is thus in a historiographical context that these orientalist discourses must be put in perspective, in order to surpass generalist approaches:

the critique of colonial representations appears increasingly abstract and disengaged with both its own history as well as the specific colonial histories that it seeks to explain. (Burke, Prochaska, 2008: 2)

Although both the texts and the historical contexts may be autonomous, they are dialectically entwined, thus building each other.

When we analyse stories dealing with China, and more specifically with Macao, one must bear in mind that these discourses unfold from, in Delacroix's words:

une tension indépassable entre le souci de rendre compte de ce qui s'est passé et un questionnement qui émane, pour l'essentiel, du présent de l'historien. (Delacroix et all, 2010: 18).

Orientalist signs emerge from daily life representation in the History of Portuguese presence that started to be written since the 16th century.

This aspect gains a particular strength when we ponder on certain rituals such as the so-called "tea-cult" that go along with the making of an oriental imaginary. These rituals are signalled out through the centuries in those texts that describe European presence in China and Japan. 
One must remind of both Wenceslau de Moraes' 19th century book on this topic and Eça de Queirós' Mandarin, where we find a passage about it.

In the 16th century, Friar Gaspar da Cruz's Treaty where is detailed told the things of China with their peculiarities and the kingdom of Ormuz (1569) already mentions the fact that the Chinese offered their foreign guests a red beverage, which they called tea (D'Intino, 1989: 202). In Father Matteo Ricci's Histoire de l' Expédition Chrétienne au Royaume de la Chine 1582-1610 we find an explanation about the way both Chinese and Japanese prepared this beverage, the same thing happening in the first part chapter three of Father Álvaro Semedo's Report of the Great China. This ritual actually was a social sign of the hospitality, which should be offered to visitors.

However, all these references about the tea-cult and ritual are placed in a wider historic and cultural context. The idea of empire lies at the centre of these historiographical texts. In the 16th century, Portugal aimed to be a Respublica Christana, under the emperor's sceptre, as a propagator of the true faith upon the earth. Under this sign, a New Golden Age should emerge. The somehow constant contact with Eastern lands modelled a EuropeanPortuguese identity that was getting in touch with new realities. It is no accident that those who write these texts help themselves with their own European references in order to explain the different, the Other.

Both Duarte Barbosa and Fernão Lopes de Castanheda claimed that the Chinese language reminded of German. Tomé Pires also stated that: They wear round silk net caps like the black sieves we have in Portugal. (Pires, 1944: 116)

In this vein, Gaspar Correia mentions the fact Canton is as big Évora, and João de Barros writes that the Chinese sound like Greeks. A good example of the comparative strategy between Europe and these Eastern lands is Luis de Fóis' late 16th century Treaty of brief and succinct contradictions and differences of social mores between the people of Europe and this province of Japan.

In the mid-16th century, the Casanatense Codex shows a drawing about the differences between Japanese clothes and European ones. These watercolours of peoples from the Cape of Good Hope to China had, however, a limited circulation in Europe.

Until the early 17th century the cartographic knowledge of Chinese lands lied mainly on Giacomo Gastaldi' map, which had been drawn around fifteen sixty-one at the request of the Venetian senate. Europe actually was eager of narratives of Asian lands, namely China.

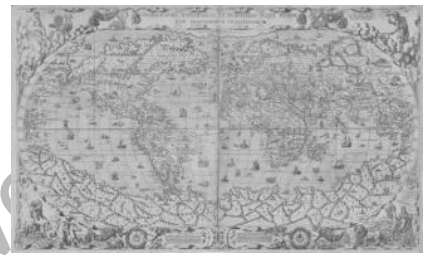

Fig. 1 Giacomo Gastaldi, Planisphere http://www.wikiwand.com/it/Planisferi_ del_XVI_secolo

The cultural world also wanted to know these new spaces. I must point out just one example, the one of Montaigne, who, although focused on South America, also read works such as Simon Goulart's History of Portugal. The Chinese:

En la plupart de leur maniere de viure ils se gouuernent à la façon des François \& Alemans, prenent plaisir d'ordinaire à iouer, rire, danser, \& boire dautant. (Goulart, 1588)

Montaigne also got in touch with other authors, like Juan Gonzalés de Mendonza's French printing of History of the things, rituals and mores of the great Kingdom of China (1585). D. E. Mungello informs us that Mendoza:

(...) was sent in 1580 by way of Mexico to China, carrying a letter to the Chinese emperor from Philip II of Spain. He encountered difficulties in Mexico, however, and was forced to return to Europe. He never actually visited China, but while in Mexico obtained materials dealing with China from Spanish 
missionaries based in the Philippines. Later in Rome, he used these materials to write his Historia, the first European work to provide detailed information on China. (Mungello, 1989: 184)

After having spent some time in China both Matteo Ricci and Álvaro Semedo wrote their Works about this space. These encounters allowed the rising curiosity about them. Ricci even tried to map this wide realm.

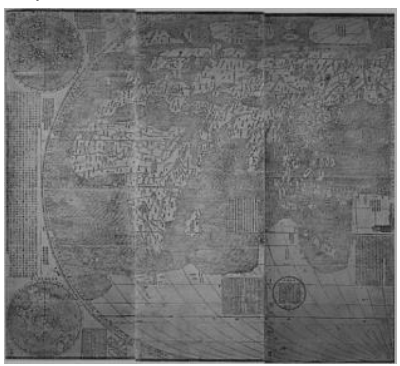

Fig. 2 Left side, 3 panels of the Kunyu Wanguo Quantu, A Map of the Myriad Countries of the World, by Matteo Ricci https://commons. wikimedia.org/wiki/Fil e:Kunyu_Wanguo_Quantu_by_Matteo_Ric ci_Plate_1-3.jpg

It is not my aim to make an exhaustive description of the evolution of European knowledge about China. Yet one must remind the fact that the descriptions of those spaces started as early as the first Portuguese contacts with Eastern lands. The Chinese seas are mainly described in the 16th century by the texts such as Fernão Lopes de Castanheda's, João de Barros', and Gaspar Correia's Expansion chronicles about the Portuguese presence in Asia (Avelar, 2003: 15-17). Damião de Góis' and Jerónimo Osório's chronicles on King Manoel and Francisco de Andrade's on King John the third provide further information on this topic. Duarte Barbosa's and Tomé Pires' travel reports, Afonso de Albuquerque's policies described by his son Brás de Albuquerque, António Galvão's Discoveries Treaty, Fernão Mendes Pinto's pilgrimage, and other missionary texts provide further descriptions about China (Loureiro, 2009: 181).
In these different historiographical discourses, the Chinese seas emerge as one of the multiple spaces where Portuguese domain lies. These narratives often repeat early information about this space and these peoples provided by Duarte Barbosa's and Tomé Pires' early reports (c. 1515-1516). Along these early data, each author emphasizes those dimensions he considers more relevant.

The textual matrixes for this early group of texts are those written by Tomé Pires and by Duarte Barbosa. We must bear in mind that both authors follow the same narrative structure. In Summa Oriental:

The king of China is a heathen with much land and many people. The people of China are white, as white as we are. Most of them wear black cotton cloth, and they wear sayons of this in five pieces with gores, as we do, only they are very wide. In the winter they wear felt on their legs by way of socks, and on top well-made boots which do not reach above the knee, and they wear their clothes lined with lambskin and other furs. Some of them wear pelisses. (Pires, 1944: 116)

The chronicler compares the way of dressing with the European:

They wear round silk net caps like the black sieves we have in Portugal, they are rather like Germans. They have thirty or forty hairs in their beards. They wear very well-made French shoes with square toes. (Pires, 1944: 116)

Tomé Pires also refers daily life habits, such as food, meat and beverages that are consumed by the Chinese:

All the Chinese eat pigs, cows and all other animals. They drink a fair amount of all sorts of beverages. They praise our wine greatly. They get pretty drunk (...). Those who are to be seen in Malacca are not very truthful and steal - that is the common people. They eat with two sticks, and the earthenware or china bowl in their left hand close to their mouth, with the two sticks to suck in. This is the Chinese way. The women look like Spanish women. (Pires, 1944: 116)

On the other hand, according to Duarte Barbosa:

The inhabitants of the country are white men, tall, well-made and gentlemen; and so likewise the women. They have got only one defect, that their eyes are very small, 
and on their chins, they have three or four hairs and no more; the smaller their eyes are, so much the prettier they think them; and the same as regards the women. They are very smartly dressed, clothed in silk and cotton and woollen stuff, and their costumes are like those of Germans; they are shod with soft leather boots and shoes, like the people of a cold country. They have a language of their own, and the tone of it is like that of Germans. (Dames, 1989: 213)

Barbosa provides detailed information on this Chinese daily life that Tomé Pires has already mentioned:

They drink several kinds of wine, and many times during their meals. They also eat the flesh of dogs which they hold to be good meat. They are men of truth and good gentlemen: they are great merchants of all sorts of goods. They make much porcelain in the country, and very good, which is a great article of commerce for all parts. (Dames, 1989: 213)

Besides the porcelain, Barbosa lists a whole series of goods that delight the Europeans:

There also grows and is produced in this country of China much very good silk, of which they make a great quantity of stuffs; that is to say, damasks of all colours, satins of several kinds, and brocade. There is much rhubarb in this country, and much musk, very fine silver, seed pearl, and pearls that are not very round. Many of these Chinese take their wives and children continually in the ships in which they live without possessing any other dwelling. (Dames, 1989: 214)

The second group of texts reveal the report of the authors' permanencies on Chinese seas. This is what happens in rather different narratives such as Cristóvão Vieira's, Vasco Calvo's and Galiote Pereira's letters and Friar Gaspar da Cruz' Treaty of the Things of China, which is the first printed book about China that gets European circulation.

The author points out information about spaces and peoples. After an aesthetic description of the way they look, Friar Gaspar da Cruz provides detailed information about the way they both women and men dress, and about their social behaviour. ((D'Intino, 1989: 202).

Friar Gaspar da Cruz also emphasizes the civility that, in his view, lied at the core of Chinese social behaviour.

Narratives about China keep on gathering information and details about both physical and social fields, often based on daily experience. Yet these descriptions follow the points of view that we find in earlier Portuguese narratives on Asian lands. This is a focus that emerges from the sea towards the land; a point of view that evolves in time anchored in the visual observation.

Father Manuel Teixeira's letter written on the December the first fifteenth sixtythree, reveals Macao from geographical coordinates, along with the description of the Chinese's complexion.

The permanence both in China and in Macao echoes in the way these authors tell their story. Historic time is conceived as linear and progressive, entwined with memory which somehow plays the role of discourse building. On the other hand, commemorative reminiscence is key in Fernão Mendes Pinto's Pilgrimage.

Macao emerges as space where the Portuguese feel as confident and secure as if they were in Portugal (Alves, 2010: 776).

Its importance somehow echoes in Pedro Barreto de Resende drawings of Macao's square in his Book of Drawings of All the Fortresses, Cities and Towns in the Eastern State of India. António Bocarro (Goa, February seventeenth sixteen thirty-five) also conceived his drawing according to Fernão Mendes Pinto's memory.

We are not yet before an idea of progress, since all these texts only confront the different, either incorporating it or rejecting it. On the other hand, as we have shown above the historical time that emerged in historiographical discourse about China and Macao followed a progressive linearity, rather than a cyclic one, which still prevailed in Eastern shores.

During the following centuries, this progressive linearity had a great impact on the way both narratives and visual representations depicted a space, the Eastern/Chinese one, and an empire, the Portuguese one. In addition to being an 
important element for us to understand coeval reality, those texts functioned as a matrix for other texts to come. Knowing them allow us to get a more rigorous insight about the different nuances of a topic that, even silently, stood at the core of the encounter with the Other; as Walter D. Mignolo has stated: "understanding the past [is] to speak the present.” (Mignolo, 2003: 455).

\section{Bibliographical References}

Alves, Jorge S.dir. (2010) Fernão Mendes Pinto and the Peregrinação, Lisboa: Fundação Oriente.

Avelar, Ana Paula (2003). Figurações da alteridade na cronística da Expansão, Lisboa: Universidade Aberta.

Avelar, Ana Paula (2010). Construindo um conceito: 0 Orientalismo nos primeiros escritos portugueses sobre a China e Macau. In Macau na Escrita, Escritas de Macau, Lisboa: Edições Húmus e CEC.

Burke, E. Prochaska, D. (2008) Genealogies of orientalism: history, theory, politics, Neb.: University of Nebraska Press.

Delacroix, C. et all (2010). Historiographies, I, Paris, Editions Gallimard.

D'Intino, Raffaella (1989). Enformação das cousas da China -textos do século XVI, Lisboa: IN-CM.

Dames, Mansel (1989). The book of Duarte Barbosa..., New Delhi: Asia Education Services.

Goulart, Simon (1588). Histoire de Portugal, contenant les entreprises, nauigations \& gestes memorables des Portugallois... comprinse en vingt livres... traduits du latin de lerosme Osorius..., les huit suiuans prins de Lopez de Castagnede et d'autres historiens... Paris: Abel l'Angelier.

Loureiro, Rui Manuel (2009) Nas partes da China, Lisboa: CCCM.

Mignolo, W. (2003) The Darker side of the Renaissance, Mich: the Michigan University Press.

Mungello, D.E. (1989) Curious Land-Jesuit Accommodation and the Origins of Sinology, Honolulu: University of Hawaii press.

Pires, Tomé (1944).Summa Oriental of Tome Pires and the book of Francisco Rodrigues, London: Hackbut Society. 